[Wells, C. (1999). Future Directions: Shaping Early Childhood Education Policy for the 21st Century - A Personal Perspective. New Zealand Annual Review of Education, 8, 45-60]

\section{Future Directions: Shaping Early Childhood Education Policy for the 21st Century - A Personal Perspective}

\section{CLARE WeLlS}

\section{Abstract:}

The report of the Early Childhood Education Project - Future Directions: Early Childhood Education in New Zealand was launched in September, 1996. The report "focuses on the structures and funding required to deliver high quality education services for young children" (Early Childhood Education Project, 1996a, p. 2). This article briefly describes the context within which the project was initiated. It outlines the aims of the project, the process undertaken to develop the report and highlights its key findings, goals and recommendations. This article sets out NZEI Te Riu Roa's strategy in promoting the report and concludes with a broad overview of the impact of the report in shaping government policy direction.

n 1988, Education to be More, the report of the Early Childhood Care and Education Working Group (Meade Report) described a 1 progressive framework for early childhood education policy development (Wells, 1997). The Meade Report focussed on achieving high quality early childhood education and unifying policies across the early childhood sector in line with the structural and administrative changes to be put in place for the primary, secondary and tertiary sectors of education.

In 1989, the Prime Minister and Minister of Education David Lange introduced Before Five: Early Childhood Care and Education in New Zealand. Before Five was the policy document that followed on from the Meade report. Lange (1988) described the new policy as building

... upon existing strengths of the various services and centres.

Community involvement and professional expertise have been the
46 Clare Wells

two driving forces in developments to date. This policy is based on these two strengths, and the co-operative spirit which has become so much part of the ethos of this sector .... Improvements in this sector are an investment in the future. Our children are our future. They need a good start in life. I believe Before Five will give them that.

In 1989, the Department of Education was replaced by the Ministry of Education. Many of the Department's functions were taken up by new agencies including the Special Education Service, the Review and Audit Agency, and specifically for early childhood, the Early Childhood Development Unit (ECDU). The ECDU was established to assist the development and co-ordination of new services (Meade, 1994).

\section{Before Five policy}

The Before Five policy outlined the initiatives to be put in place for early childhood education, but did not provide the necessary funding arrangements (Meade, 1994)

The policy also differed from that for the schools sector on three significant counts. Firstly, there would be no board of trustees structure to promote a democratic and inclusive approach to decision-making at the centre level, and secondly, there would be no separation of salary and operational costs in the bulk grant to services. Thirdly, private for-profit childcare centres were to receive government funding on the same basis as community-based centres (Mitchell, 1993).

It was the following year, in 1990, that the Labour government announced a significant increase in funding to early childhood services, to be phased in over a period of three years $-\$ 43$ million, a 125 percent increase - to support the Before Five policy. In his speech announcing the funding increase to representatives of the early childhood sector at Kelburn Playcentre in Wellington, David Lange likened the process of winning the funding to "snatching raw meat from the jaws of a rotweiller" (Wells, 1997).

The early childhood sector had a sense of optimism that finally the government had implemented a comprehensive policy and backed it up with the necessary funding to secure a viable future. However, as Dalli (1994) explains, "the optimism was short lived. The gains made in the years between 1986 and 1990 were swiftly undermined."

New government - New direction

In October 1990, there was a change of government, with the National party winning the election. Two months later, on 19 December 1990, the 
Prime Minister Jim Bolger announced the government's Economic and Social Initiative. This set out the government's policy direction for health, welfare, housing and education, industry training and employment (Bolger, 1990). The policies were based on four key principles: fairness (targeting those in most need); self reliance (taking care of yourself); efficiency (highest return for the tax dollar); and greater personal choice (alternative providers).

In setting out these principles, the government foreshadowed that its approach to future policy development would be based on neo-liberal theory rather than on the collective or public good approach, and on targeted funding rather than universal funding to services. The government foreshadowed its support for the privatisation of services and reliance on the market to deliver services where demand dictated. (Boston, 1991; Wells, 1998) The government intended to reduce its role in developing and supporting comprehensive and cohesive policy initiatives in conjunction with the early childhood sector (Mitchell, 1995).

The year 1991 saw no fewer than seventeen reviews in education, four being on early childhood education matters. The early childhood reviews targeted the core changes recently implemented through the Before Five policy - funding; staffing, qualifications and training; properties; and the Early Childhood Development Unit (Meade \& Dalli, 1992). Officials carried out the reviews behind closed doors with no direct input from the sector. Over 3,000 submissions were sent to the review group on early childhood funding. The Combined Early Childhood Union of Aotearoa CECUA (1993a) reported that:

None of these submissions supported the eventual government policy decisions to reduce funding to under two year olds and the contribution of early childhood organisations and professionals was largely ignored. In fact, the submissions were not read by most of the review group members.

The results of the reviews were announced by the Minister of Finance Ruth Richardson in the July 1991 government budget. A range of measures was announced which reduced standards and levels of funding. As Mitchell (1993) summarised:

- registration for kindergarten (and primary and secondary) teachers was made voluntary;

- the funding rate to centres for children under two year of age was cut by 50 percent;
- new regulatory requirements for licensing, and therefore the receipt of government funding, for the "person responsible" in a centre were amended. This meant that a "person responsible" in a centre did not have to have a recognised qualification, merely a collection of "licensing points";

- a greater emphasis was placed on targeting funding to low income families through a social welfare subsidy.

Dalli (1994) notes, "the decisions of that Budget continue to reverberate through the early childhood sector and can be identified as major contributors to the problems which now face the sector."

CECUA surveyed its members within eight months of the Budget announcements taking effect. The report of the survey concludes that "Childcare centres had been poorly funded before those cut-backs, and the effects have magnified the inadequacies that already existed .... There is compelling evidence that quality of education is compromised" (CECUA, 1993b, p. 11)

\section{Future Directions}

It was within this context that NZEI Te Riu Roa, the education sector union then representing early childhood professionals, resolved to work with other early childhood sector organisations to develop proposals "that will take the whole sector forward on a sound basis into the 21st century" (Early Childhood Education Project, 1996a, p. 2).

NZEI Te Riu Roa initiated the Early Childhood Education Project in April 1995. Dr Geraldine McDonald, a credible and well known educationalist, accepted the invitation to chair the project. As she says in the foreword of the final report, Future Directions:

In the last seven years early childhood education has had its fair share of change .... A feature of the early childhood policy development has been the carrying out of "top down" reviews .... There appears to have been an erosion of high quality publicly funded early childhood education.

(Early Childhood Education Project, 1996a)

\section{The project team}

The project team membership was composed on the basis that employees, employers and tangata whenua, and each type of community-based early childhood service, were represented. Where there was more than one representative group in each of these services, the largest group was invited to participate. The team represented the 
New Zealand Childcare Association/Te Tari Puna Ora o Aotearoa, Te Kohanga Reo Trust, New Zealand Free Kindergarten Associations, Pacific Islands Early Childhood Council of Aotearoa, New Zealand Playcentre Federation, New Zealand Family Day Care Association, and NZEI Te Riu Roa. NZEI Te Riu Roa funded the project and provided the secretariat and research.

The project aimed to:

- $\quad$ provide a rigorous and coherent review of the current situation of early childhood education in Aotearoa/New Zealand and the access of children to it;

- contribute towards a comprehensive policy for Maori education;

- recognise and value diversity of organisations, cultures and communities

- examine the relationships between the work of various government agencies and the early childhood providers in order to establish their contribution to quality education for young children;

- examine the extent to which government legislation supports quality education for young children;

- develop proposals on the structures and funding required to ensure quality education for young children;

- $\quad$ build widespread understanding and support for the proposals. (Early Childhood Education Project, 1996a)

The timing of the project was critical. The project team came together in the middle of the National government's second term in office. It worked towards publishing the final report in the lead up to the 1996 general election in order to publicly promote early childhood education during the election campaign and influence government and opposition party policies prior to and after the election.

The project team identified that the key to the success of the project would be genuine consultation with practitioners and service providers in early childhood education. They wanted to hear from people working "out there" in the sector.

\section{Interim report - June 1996}

The first round of consultation resulted in the release of an interim report which was launched at a gathering organised by the project team in June, 1996. The launch was attended by government officials, including representatives from the Ministry of Education, Early Childhood Development Unit and the Education Review Office, early childhood sector practitioners, researchers, academics and the media.
The interim report was based on:

- discussions by the project team;

- an analysis and review of current policies, demographic information, enrolment and participation figures, funding levels and administration guidelines

- consultation meetings with practitioners and providers from around New Zealand;

- consultation with national representatives of some early childhood organisations;

- consultation with six government agencies involved in early childhood education.

(Early Childhood Education Project, 1996b)

As a result of the review of the current situation within early childhood education and consultation with the sector, the key issues that emerged were the difficulties early childhood services had in four areas: managing the funding and administration of the services; meeting the costs under the present level of funding; providing access to all families; and relationships with government agencies (Early Childhood Education Project, 1996b). The interim report described how the project team had reached its conclusions and noted that its approach "enabled the project team to develop proposals that build on existing arrangements while discarding unsatisfactory policies" (Early Childhood Education Project, 1996b).

The interim report presented recommendations on structural and funding arrangements based on the principles that services should be of high quality, accessible to all communities and treated on an equitable basis with schools. It was sent to early childhood practitioners and organisations for comment and distributed far and wide and promoted through the media. This activity resulted in a high level of public interest about the current state and status of early childhood education and the government's track record in relation to the development and implementation of policy.

Feedback on the interim report was included in the final report, Future Directions, which was launched at the Beehive in September 1996 - the month prior to the general election.

\section{Future Directions - the proposals}

Future Directions confirmed the benefits of quality provision and gathered evidence on the barriers to services achieving their own goals of high quality. The project team concluded that unless the structural 
and funding difficulties were addressed, early childhood education services would continue to be frustrated or fail in their attempts to provide quality early childhood education.

The project team proposed three broad goals for the future direction of early childhood education policy and a series of recommendations to be realised in meeting these broad goals. The goals were:

- That the long-term goal for early childhood education services is to be universally funded on a basis that is equitable with the schools sector by the year 2000. Just as the government funds the schools sector it should in the same way fund early childhood services.

- That the development of policy at national, regional and local levels be undertaken as a partnership between the government, providers, practitioners and parents/caregivers.

- That the government develop a strategic plan for early childhood as a sector. The consultation process should include representatives from Health, Social Welfare, Education, Justice and parents. The strategic plan should include how society can offer holistic support to families/whanau raising young children.

(Early Childhood Education Project, 1996a)

The report's 23 recommendations included that:

- a staged plan be developed to increase funding to services;

- a ministerial group be set up to determine how funding can be linked to quality;

- a universal base funding rate be established to cover staffing, ratios, group size and qualification requirements;

- additional equity funding be available to services;

- funding for specialist education support, provision of professional development on special education, and the national co-ordination of services be available;

- funding be available to assist staff to upgrade their qualifications;

- staff and parents/caregivers be represented on management committees;

- unlicensed centres be supported to reach licensing;

- government agencies improve co-ordination;

- the Ministry of Education improve co-ordination and consistency of advice.

The report presented costings and proposed a three stage plan for implementation of the recommendations.

\section{Future Directions - the political reaction}

The Associate Minister of Education Bill English, Leader of the Opposition the Right Honourable Helen Clark, United Party spokesperson on education Margaret Austin, and Alliance Party spokesperson Dana Glendinning spoke at the launch of Future Directions, as well as representatives from each of the early childhood groups on the project team.

In her speech Helen Clark commended the report, saying, "What makes the report highly credible is that the project team itself was broadly based, and there was very extensive consultation throughout the sector" (Clark, 1996).

Margaret Austin described the report as being "about the most significant document to emerge in the lead up to election 96" (Austin, 1996). She told the project team "What you have shown very clearly is that you understand the meaning of participatory democracy and can use it to advantage. It truly is from the heart of the whole service" (Austin, 1996).

Although the report received high praise from within the early childhood and wider education sectors, political parties, and interested organisations such as the Women's Division of Federated Farmers, this praise was not forthcoming from the government. All except the Minister hailed the report as a major and significant piece of work. Bill English, in his media release on 23 September 1996, said the report "ignored all the positive developments in the sector for children and their parents" (English, 1996).

Government officials attempted to "play down" the report and divert political discussion away from its recommendations on the basis that the government had increased funding to early childhood education in recent years and, perhaps more significantly, because the project team did not include representatives of the for-profit childcare centre owners. Bill English claimed that because these people were not involved, the report could not purport to represent the whole sector. The Minister, furthermore, attempted to undermine the report by referring to it as "the NZEI report". In his media statement on 23 September 1996, Bill English concludes:

The NZEI report does not acknowledge the efforts of staff and parents who have worked so hard to do a better job for the children. It is a pity that the report claims to represent all the early childhood sector when many people in the sector have approached me to say they do not support the recommendations. 
There's nothing wrong with lobbying for more funding, but to criticise everything that is happening in the sector is not very constructive. The release of the report now smacks of political timing, which is not going to help their cause.

(English, 1996)

The Minister ignored the fact that the project group represented the majority of the sector and, through its consultation, gathered wideranging views from practitioners in both community based and forprofit services. He was quite correct that the release of the report "smacked of political timing". This was deliberate on the part of the project team to ensure early childhood education maintained a high public profile and the effects of government policy were exposed during the election year. The project team, furthermore, sought to influence and shape the policy agenda following the general election.

\section{Promoting the Report}

The report's findings and recommendations captured media attention and were featured in regional and daily newspapers nationwide. The media carried a strong message to the government that their policies were failing our youngest citizens.

The Labour, Alliance and New Zealand First political parties moved immediately to reflect the recommendations in the report within their policies. New Zealand First quoted directly from the report, establishing policy to "adopt a long-term goal for early childhood education services to be universally funded on a comparable basis with the schools sector" (NZEI Te Riu Roa, 1997a).

\section{The strategy}

Once the report was released, the organisations involved in the project set about using the report to raise the issues publicly and to lobby politicians. The first part of the strategy was to encourage early childhood education organisations to adopt the report, and therefore its recommendations, as policy. NZEI Te Riu Roa was the first organisation to do so in 1996.

A summary of the report and its findings was made available to all organisations. Project team members presented the report to the Federation of Early Childhood Education Organisations (FECEO). FECEO agreed to support the report and "assist in promoting it by writing letters to relevant government agencies and individuals" (FECEO, 1997, p. 2). Future Directions was raised at Ministry of
Education Early Childhood Advisory Committee (ECAC) meetings. NZEI Te Riu Roa took the lead to ensure Future Directions remained an agenda topic and part of any discussion on early childhood matters (NZEI Te Riu Roa, 1997b).

\section{Influencing the government}

Once the new coalition government emerged in late 1996, all Members of Parliament were sent a letter, a copy of the report and an invitation to meet with project team members. Members of the team met with a number of individual politicians from all parties, with the Labour Party Caucus, and with the Alliance spokesperson on education.

NZEI Te Riu Roa launched a campaign in early 1997 aimed at influencing the government to increase funding rates to early childhood services as proposed in the report. The campaign was spearheaded in regions by NZEI Te Riu Roa members who worked with practitioners from other early childhood services to lobby their local politicians and to gather public support.

A “10 Day Plan" (NZEI Te Riu Roa, 1997c) was distributed through NZEI Te Riu Roa networks which gave people the information they needed for lobbying, including a summary of the report's recommendations, fact sheets on current funding, a timeframe and suggestions for action, and a method of planning and reporting on local activities. The campaign included a petition to government and concluded with a national day of action on May 1, 1997 - "May Day, May Day - Red Alert" (NZEI Te Riu Roa, 1997c).

The petition was a critical part of the campaign and its purpose was two fold: (i) to build up public support for the report and demonstrate that support to the government; and (ii) to ensure Future Directions remained "in front" of government politicians and officials for as long as possible, and thereby increase the likelihood the report would be considered in policy development and influence government Budget decisions.

The petition called on the government to adopt the recommendations of Future Directions by "allocating an additional $\$ 40$ million to early childhood services, developing a long term strategy for early childhood education in consultation with the sector during 1997/98, and planning for the delivery of equity funding to early childhood services in 1998/99" (NZEI Te Riu Roa, 1997d).

People signing the petition were encouraged to deliver the completed petition to their local Member of Parliament who in turn was 
obliged to present it and read it out in full to Parliament. The petition gathered over 14,000 signatures within a few months and the number of petitions being read in Parliament led to its referral to the Education and Science Select Committee for consideration.

\section{Select committee hearings}

In 1997, the select committee called for submissions and invited petitioners to present their views and back up their support for the petition to the committee. In a not-too-common move, the committee set up hearings around the country in Auckland, Hamilton, Palmerston North, Christchurch and Dunedin, as well as three hearings in Wellington.

NZEI Te Riu Roa organised people to attend each hearing. Information packs were designed and distributed, providing background and statistical information and a brief biography of each of the select committee members.

\section{The Ministry's response}

The Ministry of Education made a written submission to the select committee on September 2, 1997, and was subsequently requested to appear before the committee to present its view on the petition and on the recommendations in the report. In its introductory statements to the submission, the Ministry chose to highlight that the project team did not include the Early Childhood Council (ECC) and in so doing, it ignored the rationale for the selection of project team members (see pp. 46-47). The Ministry noted, "The Early Childhood Council, which represents mainly private early childhood education providers was not represented on the project team" (Ministry of Education, 1997, p. 2). This implicit criticism reflected the approach taken by the Minister at the launch of the report some twelve months earlier.

Of one of the key goals in the report, the Ministry stated that it "does not believe that it is necessary or appropriate to develop a strategic plan for the early childhood education sector" (Ministry of Education, 1997, p. 3). The Ministry presented current government policy and policy initiatives in response to each of the report's recommendations. They made little attempt to analyse the report's recommendations in terms of what may be required, appropriate or possible, or to accept the issues and concerns raised by the sector in the report as legitimate and valid.
The Secretary of Education, Howard Fancy, appeared before the select committee on November 20, 1997, to present the Ministry's submission on the report. When asked what he thought of the report he said it was well researched, had useful information and that the Ministry would look at the report's recommendations. The New Zealand First list Member of Parliament on the committee, Neil Kirton, asked why then, did the Ministry not state this view in its submission?

Two select committee hearings were held in Wellington in 1997, and a further hearing on August 13, 1998. The Ministry appeared again at the 1998 hearing saying it "was attempting to address some of the issues in the report ...[and] also considering ways in which services can be better supported by Government agencies" (NZEI Te Riu Roa, 1998, p. 1), and described key policy developments underway on qualifications and regulations, and quality funding. At that same hearing, Liz Gordon, Alliance spokesperson on education commented to the Ministry official present, Brenda Burke, that the Ministry seemed "much more positive about the report than it had been last year and its response represented a change in direction" (NZEI Te Riu Roa, 1998, p. 1).

After the August 13, 1998, hearing, the committee advised it would not be making any recommendations to Parliament on the petition. It was satisfied that the Ministry was already working on a number of the issues raised in the report. Although the select committee decided not to make any recommendations on the report, Future Directions had been kept "in front" of politicians and officials for nearly two years.

\section{Influencing Policy Direction}

Since the project was initiated in April ,1995, there have been a number of policy changes. Many have a direct link to the issues raised by the early childhood sector through the consultation, interim and final reporting stages of the project. Although not all of these changes can be attributed to Future Directions, it can be argued that the project had a significant impact. The government through the Ministry of Education has:

- increased funding to services by $11 \%$ (quality funding) in $1995,2.6 \%$ in $1996,5 \%$ in 1997 , and $2 \%$ in 1998

- announced quality funding criteria in the 1995 Budget for services other than kindergartens, acknowledging that the presence of staff holding the Diploma of Teaching and higher child:staff ratios have a direct relationship to the quality of the programme; 
- focussed on the need to increase support for Pacific Islands education through its employment initiatives, and provide more funding to assist centres to become licensed as a result of the government's Employment Taskforce report in 1997;

- started to consider the issue of equity funding in 1997;

- worked in collaboration with other agencies, including health and welfare, on joint projects such as the 1997 initiative, the Strengthening Families Project;

- consulted the early childhood sector over the resource documents for the implementation of the revised Statement of Desirable Objectives and Practices during 1997;

- continued its support for early childhood curriculum document Te Whaariki and increased funding for professional development by $\$ 4$ million in the 1997 budget;

- reviewed internal (Ministry of Education) structures in 1997 to provide better cohesion and consistency of policy development and advice (Ministry of Education, 1997);

- implemented "pathways programmes" in 1997 to give early childhood practitioners access to programmes to upgrade their qualifications to the Diploma of Teaching;

- prioritised 1997/1998 contestable funding to training providers delivering upgrading programmes to the Diploma of Teaching (Ministry of Education 1996),

- $\quad$ started to examine, in 1997, the level of support for services to meet regulatory needs;

- contracted the New Zealand Council for Educational Research (NZCER) in 1998 to provide options for linking qualifications to regulations;

- contracted the NZCER in 1998 to develop phase one of a plan to link quality to funding;

- considered ways in which services can be better supported by government agencies.

(NZEI Te Riu Roa, 1998, p. 1)

These policy developments relate closely to the broad goals and recommendations outlined in Future Directions. Of particular significance, is the level of consultation and involvement of the early childhood sector in a number of these developments (Mitchell, 1996). After the sector had effectively been locked out of the policy development process between 1990 and 1995, the Ministry of Education subsequently adopted a more inclusive approach, and it became clear through the activities of the last two years that the Ministry is now actively seeking and encouraging consultation with the sector prior to final reports or decisions being taken.

The Ministry of Education has never stated that it views Future Directions as being central to its policy development. However, the high degree of correlation between the issues raised within the report, and those in the Ministry's policy development plan, seems to be too much of a coincidence to ignore.

In addition, it is interesting to note a standard presentation given by Ministry officials on the role of government and the development of early childhood policy includes a section on current policy issues. In 1998, this section of the presentation is called "Future Directions" and highlights the regulatory environment, quality indicators and qualifications as key policy areas.

\section{Conclusion}

Future Directions highlighted both the positive benefits of quality early childhood education and the difficulties services had in meeting and maintaining quality objectives. The process involved in developing the report, and its findings and recommendations, reflected a genuine need from the early childhood sector to "get it right". It was a major, collaborative piece of work which unified the early childhood sector to identify, state and strive towards structural and funding arrangements in support of quality early childhood education. As Margaret Austin told the project team on the day of the launch of the project, "It truly is from the heart of the whole service" (Austin, 1996).

The influence of the private, for-profit childcare centre owners on government officials, and the government's own view of a reduced role for the state, encouragement of contestability and market models of operation, conspire against and create barriers to achieving the goals set out in Future Directions. However, even in such a climate, there is clear evidence that the report has had an effect. The extent to which this is the case is yet to be realised.

The Ministry's policy development stops short of providing a comprehensive plan for early childhood education. Developments seem to be in "unconnected parts" making it difficult to plan in one area of policy without knowing the results of another. Until the outcome of the Ministry's work on current policy initiatives is known, the early childhood sector cannot rely on the government to adopt an approach which better meets the needs of the sector. 
The Future Directions report is just as relevant in 1998 as it was in 1996. It provides the evidence to support the sector's call on the government for improved structures and funding that support and promote, rather than hinder, the delivery of quality early childhood education in Aotearoa New Zealand.

\section{References}

Austin, M. (1996, September). Speech notes for the launch of Future Directions: Early Childhood Education in New Zealand. Wellington: United NZ.

Bolger, J. (1990, December 15). Economic and social initiative: Statements to the House of Representatives. Wellington: Government Print.

Boston, J. (1991). The theoretical underpinnings of public sector restructuring in New Zealand: Reshaping the State: New Zealand's bureaucratic revolution. Auckland: Oxford University Press.

Clark, H. (1996, September 23). Labour makes major commitment to early childhood. Speech notes for launch of Future Directions: Early Childhood Education in New Zealand. Wellington.

Combined Early Childhood Union of Aotearoa (CECUA). (1993a, October). Submission to Review of Early Childhood Funding. Wellington: CECUA.

Combined Early Childhood Union of Aotearoa (CECUA). (1993b, December). Childcare staffing survey. Wellington: CECUA.

Dalli, C. (1994). Is Cinderella back among the cinders? A review of early childhood education in the early 1990s. New Zealand Annual Review of Education 3, 223-252.

Early Childhood Education Project. (1996a). Future Directions: Early Childhood Education in New Zealand. Final Report. Wellington: NZEI Te Riu Roa.

Early Childhood Education Project. (1996b). Future Directions: Early Childhood Education in New Zealand. Interim Report. Wellington: NZEI Te Riu Roa.

English, B. (1996, September 23). Report ignores positive developments. Media release. Wellington: Office of the Minister of Education, September.

Federated Early Childhood Education Organisations (FECEO). (1997). Minutes of the FECEO Meeting held on Wednesday, February 19. Communication with FECEO members.

Lange, D. (1988). Before Five: Early Childhood Care and Education in New Zealand. Wellington: Government Print.
Meade, A. (1994, August). Before Five - 5 Years On. Keynote address to the New Zealand Association for Research in Education (NZARE) special seminar, University of Auckland.

Meade, A., \& Dalli, C. (1992). Review of the early childhood sector. New Zealand Annual Review of Education, 1, 113-132.

Ministry of Education. (1996). Minutes of the Early Childhood Advisory Committee Meeting held in Wellington on July 30.

Ministry of Education. (1997, September). Submission to the Education and Science Committee: Education Petitions. Unpublished written submission. Wellington: Ministry of Education.

Mitchell, L. (1993). The impact of Government policy in the early childhood education sector: 1987 to 1993. Directed study. Unpublished paper, University of Waikato.

Mitchell, L. (1995, September). Early childhoodeducation: Future directions. Paper presented to the Early Childhood Education Convention, Auckland.

Mitchell, L. (1996). Crossroads - Early childhood education in the mid-1990s. New Zealand Annual Review of Education, 5, 75-92.

NZEI Te Riu Roa. (1997a, February). Strategies on early childhood funding. Internal communication. Appendix 1997/101.

NZEI Te Riu Roa. (1997b, April). NZEI Te Riu Roa: Key issues to ECAC meeting. Unpublished paper.

NZEI Te Riu Roa. (1997c, April). Early childhood funding campaign. NZEI Te Riu Roa Branch Circular 1997/9.

NZEI Te Riu Roa. (1997d). Petition to House of Representatives. Wellington: NZEI Te Riu Roa.

NZEI Te Riu Roa. (1998, September). Final Select Committee hearing. Internal communication. Appendix 1998/641.

Wells, C. (1997, October). Current issues and trends in early childhoodChildren in the balance. Keynote address to the Teacher Refresher Course Committee - Course: Leadership and Management in Early Childhood, Christchurch.

Wells, C. (1998, October). Quality versus quantity in teacher education. Will the increase in the number of teacher education providers and programmes benefit education in the future? Unpublished paper.

\section{The author}

Clare Wells is an NZEI Te Riu Roa Senior Officer Professional/Industrial and was part of the secretariat for the Early Childhood Education Project. 